\title{
Determination of the Friction Factors in Potash Mines
}

\section{Marc Bascompta Massanés, Lluís Sanmiquel Pera and Josep Oliva Moncunill}

Polytechnic University of Catalonia (UPC),

Av. Bases de Manresa, 61-73 08242, Manresa, Spain

e-mail:mbascomptem@gmai.com; sanmi@emrn.upc.edu; josep@emrn.upc.edu

Received June 16, 2014

\begin{abstract}
The friction factor is an essential parameter to take into account for modelling the ventilation system. One of the principal features that define the friction factor is the roughness, which not only does it have influence on the airway resistance, but it has also a direct bearing on the rate of heat transfer between the rock and the airstream. In this paper, the characteristic friction factors of a potash mine exploited using a room and pillar method has been determined by means of the Chezy-Darcy and Atkinson equations. The results give an impulse to achieve standardized friction factor values in potash mines very useful for future mining ventilation surveys.
\end{abstract}

Keywords: Mining ventilation, friction factor, potash mine, room and pillar exploitation method.

DOI: $10.1134 / \mathrm{S} 1062739114050159$

\section{INTRODUCTION}

The knowledge of the ventilation system and the parameters that define its behaviour is crucial for modelling it [1]. Among all of them, one of the most important aspects to take into account is the friction factor, which will be basically affected by the exploitation method, geometric characteristics of the tunnels and physic conditions of the mine [2].These factors have a huge influence to the resistance against the flow of the air through the airways [3]. However, there is little information about potash exploitations, being mainly focused on coal and metal mines.

This paper give insight of the friction factors in an underground potash mine that uses continuous mining machines to exploit the mineral and carrying it to the surface through a conveyor belt system. These kinds of mines are very deformable due to the pressure from the surrounding rock, producing a considerable roughness in the surface of the galleries. This roughness can also be caused for the exploitation method, the temperature and the humidity grade.

One of the first studies concerning friction factors in mining was done by McElroy [4], which was based on data of the pressure loss collected from coal and metal mines. Many subsequent related studies adding data and determining new values have been published [5-11], even with the goal to standardise the friction factors [12], but there is still a lack of data for other exploitations than metal and coal mines.

\section{VENTILATION THEORY}

Frictional pressure drop is an essential parameter to know the ventilation conditions in an underground mine. It can be obtained using the equation below, which is a form of the Chezy-Darcy expression:

$$
p=f \mathrm{~L} \frac{\mathrm{Per}}{\mathrm{A}} \rho \frac{u^{2}}{2}(\mathrm{~Pa})
$$

where $f$ is the dimensionless coefficient of friction; Per is the airway perimeter, $\mathrm{m}$; $\mathrm{A}$ is the area, $\mathrm{m}^{2}$; $\rho$ is the air density, $\mathrm{kg} / \mathrm{m}^{3} ; u$ is the air velocity, $\mathrm{m} / \mathrm{s} ; \mathrm{L}$ is the length of the airway, $\mathrm{m}$.

Later on, it was adapted by Atkinson to the well-known Atkinson equation, expressed in frictional pressure drop:

$$
p=\mathrm{kL} \frac{\mathrm{Per}}{\mathrm{A}} u^{2}(\mathrm{~Pa})
$$

where $\mathrm{k}$ is the friction factor, $\mathrm{kg} / \mathrm{m}^{3}$. 
The same equation can also be showed in terms of resistance, using the square law, and taking into account any other air density inside the mine due to pressure or temperature factors [13, 14]:

$$
R=\frac{\mathrm{p}}{\mathrm{Q}^{2}}=\mathrm{kL} \frac{\operatorname{Per}}{\mathrm{A}^{\mathrm{s}}} \frac{\rho}{1.2}\left(\mathrm{Ns}^{2} / \mathrm{m}^{8}\right),
$$

The Atkinson friction factor is not a constant value, it varies with the Reynolds Number. However, the flow of the air in the vast majority of underground places is turbulent in nature except in few cases such as behind the stopings [15]. The Von Kármán equation gives a relationship with the friction factor from the Atkinson expression for turbulent flows. The equation is applicable to circular and non-circular airway, by means of the hydraulic mean diameter calculated with the following relationship $D h=4$ A/Per:

$$
f=\frac{2 \mathrm{k}}{\rho}=\frac{1}{4\left[2 \log _{10\left(\frac{D h}{e}\right)+1.14}\right]^{2}} \text { (Dimentionless), }
$$

where $D h$ is the hydraulic mean diameter of the tunnel, $\mathrm{m}$; $e$ is the height of the roughening, $\mathrm{m}$.

In addition, the airflow also suffers shock losses due to obstacles in the ventilation circuit like direction changes, machines, conveyors, etc. All these elements are independent of the roughness and it is not possible to include it in the friction factor. However, it can be used the equivalent length concept:

$$
\text { Leq }=\frac{0.15 X}{\mathrm{k}} D h \text {, }
$$

where Leq is the equivalen length, $\mathrm{m}$; $X$ is the shock loss factor.

The shock loss factor $X$ is experimentally determined [4, 8, 14], adding an equivalent increase in the length of the tunnel where the air flows [17]. The length increase will vary depending on the type of obstacle [18], obtaining a corrected Atkinson equation:

$$
R=\mathrm{k}(\mathrm{L}+\mathrm{Leq}) \frac{\text { Per }}{\mathrm{A}^{3}} \frac{\rho}{1.2}\left(\mathrm{Ns}^{2} / \mathrm{m}^{8}\right)
$$

\section{METHODOLOGY}

Achieving a proper ventilation system planning not only does it need a good knowledge of the ventilation laws, but it is also necessary an updated database of the ventilation features [17]. For this reason, 18 key points that stand for the principal ventilation circuit have been selected, collecting the main ventilation parameters every month from 2008 to 2013, which are detailed below. Figure 1 displays an example of the points used to obtain the friction factors.

-Geometric features of the galleries: section, perimeter, length, roughness and any permanent obstacles in the ventilation circuit.

-Dry and wet temperatures: used to control and link airway roughness and surface climate conditions

-Air velocity: knowing the section, it is possible to calculate de airflow. 


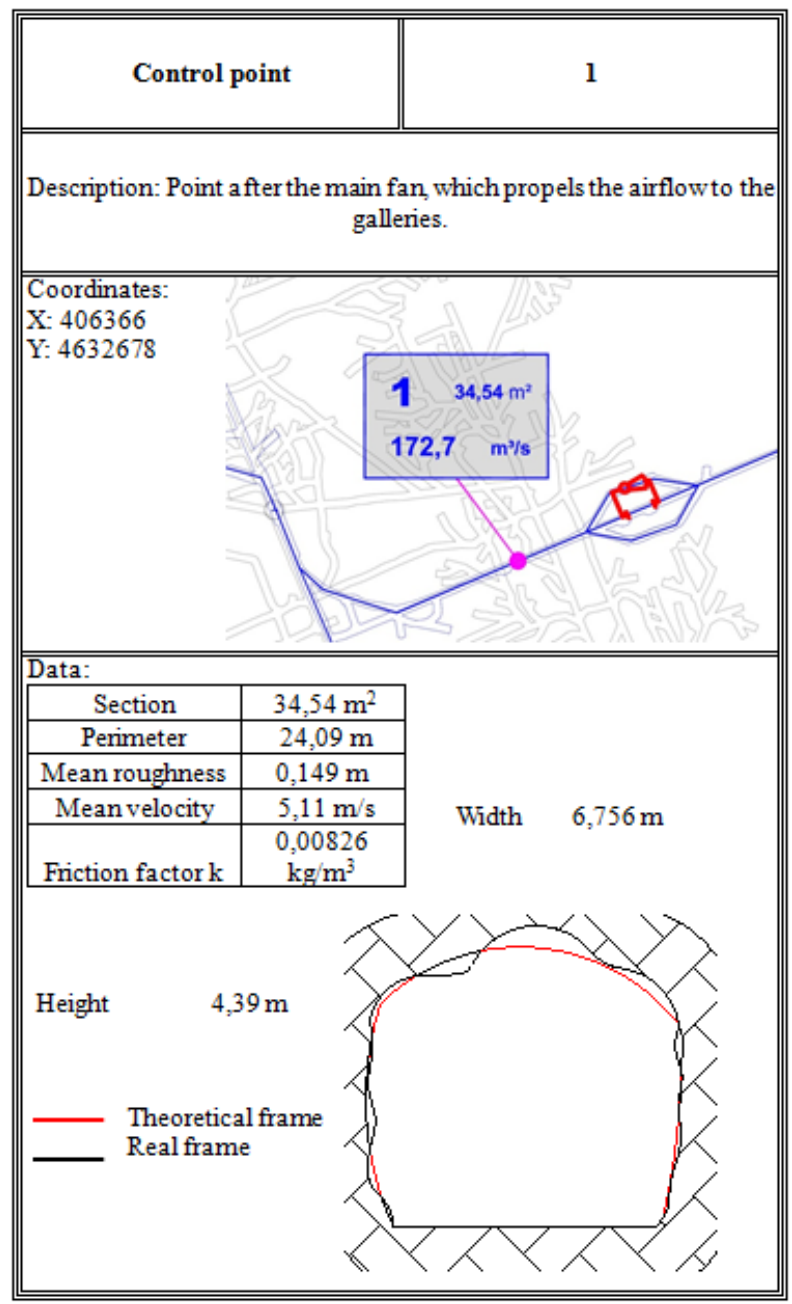

Fig. 1. Description of one of the control points.

Two important aspects in the process of calculating the friction factors have been taken into account in this paper, the Reynolds number and the hydraulic diameter. The first one is necessary to know the fluid rate and so use the proper equation and the second one to adapt the noncircular diameter of the galleries to the equations.

Once all the information detailed above has been collected, the fiction factors have been calculated for each key point four times, corresponding the four seasons of the year, because airflow and temperatures suffer an important variation during the year, affecting the friction factor result. Finally, the mean friction for each point has been obtained.

\section{RESULTS}

Table 1 shows the mean parameters used to calculate the friction factors. They have been either measured in situ or calculated with the data collected from 2008 to 2013.

The values displayed in table 2 correspond to the mean friction factors per season and the general value per point, taking into account the four seasons values in each key point, as well as the standard deviation [19].

The current bibliography details the friction factor values for coal and metal mines. Tables 3 and 4 compare the results obtained in this paper with the published data among different types of airways. Despite the survey is focused on a potash mine, not on coal or metal mines, it is possible to get a rough idea of the reliability of the results. 
Table 1. Parameters used to calculate the friction factor

\begin{tabular}{c|c|c|c|c|c|c}
\hline Point & $\mathrm{A}, \mathrm{m}^{2}$ & Per, $\mathrm{m}$ & $D h, \mathrm{~m}$ & $V, \mathrm{~m} / \mathrm{s}$ & $e, \mathrm{~m}$ & $f$ \\
\hline 0 & 40.00 & 24.60 & 6.50 & 4.42 & 0.36300 & 0.01880 \\
1 & 34.54 & 24.09 & 5.74 & 5.11 & 0.14900 & 0.01345 \\
2 & 31.84 & 22.60 & 5.64 & 0.94 & 0.14390 & 0.01336 \\
3 & 34.04 & 23.22 & 5.86 & 4.33 & 0.13260 & 0.01273 \\
4 & 27.86 & 21.85 & 5.10 & 4.36 & 0.11000 & 0.01250 \\
5 & 34.80 & 23.24 & 5.99 & 0.52 & 0.14170 & 0.01296 \\
6 & 28.37 & 21.50 & 5.28 & 0.81 & 0.23330 & 0.01687 \\
7 & 23.86 & 17.50 & 5.45 & 0.43 & 0.23750 & 0.01676 \\
8 & 31.54 & 25.00 & 5.05 & 0.38 & 0.11910 & 0.01295 \\
9 & 32.29 & 23.09 & 5.59 & 1.71 & 0.30000 & 0.01845 \\
10 & 27.83 & 22.03 & 5.05 & 4.07 & 0.18240 & 0.01543 \\
11 & 26.89 & 20.73 & 5.19 & 5.62 & 0.11440 & 0.01261 \\
12 & 24.36 & 18.00 & 5.41 & 6.40 & 0.10000 & 0.01178 \\
13 & 35.96 & 26.28 & 5.47 & 4.70 & 0.12000 & 0.01258 \\
14 & 21.61 & 20.00 & 4.32 & 0.46 & 0.17480 & 0.01622 \\
15 & 31.33 & 19.34 & 6.48 & 1.58 & 0.17480 & 0.01366 \\
$\mathrm{~A}$ & 29.82 & 21.89 & 5.45 & 0.91 & 0.30000 & 0.01868 \\
$\mathrm{D}$ & 33.40 & 23.00 & 5.81 & 0.71 & 0.23750 & 0.01630 \\
\hline
\end{tabular}

Table 2. Mean friction factor and standard deviation for each point

\begin{tabular}{c|c|c|c|c|c|c}
\hline Point & $\begin{array}{c}\text { Spring } \\
\mathrm{k}, \mathrm{kg} / \mathrm{m}^{3}\end{array}$ & $\begin{array}{c}\text { Summer } \\
\mathrm{k}, \mathrm{kg} / \mathrm{m}^{3}\end{array}$ & $\begin{array}{c}\text { Autumn } \\
\mathrm{k}, \mathrm{kg} / \mathrm{m}^{3}\end{array}$ & $\begin{array}{c}\text { Winter } \\
\mathrm{k}, \mathrm{kg} / \mathrm{m}^{3}\end{array}$ & $\begin{array}{c}\text { General value } \\
\mathrm{k}, \mathrm{kg} / \mathrm{m}^{3}\end{array}$ & $\begin{array}{c}\text { Standard } \\
\text { deviation }\end{array}$ \\
\hline 0 & 0.01163 & 0.01134 & 0.01168 & 0.01184 & 0.01162 & 0.00021 \\
1 & 0.00821 & 0.00801 & 0.00822 & 0.00838 & 0.00820 & 0.00015 \\
2 & 0.00835 & 0.00848 & 0.00835 & 0.00853 & 0.00843 & 0.00009 \\
3 & 0.00794 & 0.00778 & 0.00787 & 0.00802 & 0.00790 & 0.00010 \\
4 & 0.00781 & 0.00796 & 0.00781 & 0.00796 & 0.00788 & 0.00009 \\
5 & 0.00743 & 0.00701 & 0.00750 & 0.00739 & 0.00733 & 0.00022 \\
6 & 0.00876 & 0.00872 & 0.00875 & 0.00933 & 0.00889 & 0.00029 \\
7 & 0.00860 & 0.00856 & 0.00857 & 0.00856 & 0.00857 & 0.00002 \\
8 & 0.00894 & 0.01014 & 0.00900 & 0.00940 & 0.00937 & 0.00055 \\
9 & 0.00947 & 0.00787 & 0.00952 & 0.00900 & 0.00896 & 0.00077 \\
10 & 0.00890 & 0.00890 & 0.00900 & 0.00893 & 0.00893 & 0.00005 \\
11 & 0.00735 & 0.00729 & 0.00738 & 0.00732 & 0.00733 & 0.00004 \\
12 & 0.00690 & 0.00686 & 0.00677 & 0.00677 & 0.00682 & 0.00007 \\
13 & 0.00798 & 0.00855 & 0.00803 & 0.00821 & 0.00819 & 0.00026 \\
14 & 0.00956 & 0.00956 & 0.00963 & 0.00956 & 0.00958 & 0.00003 \\
15 & 0.00758 & 0.00694 & 0.00821 & 0.00759 & 0.00758 & 0.00052 \\
$\mathrm{~A}$ & 0.01081 & - & 0.01207 & 0.01088 & 0.01125 & 0.00071 \\
$\mathrm{D}$ & 0.00956 & - & 0.00972 & 0.00960 & 0.00963 & 0.00009 \\
\hline
\end{tabular}


Table 3. Comparison between published data and values from the paper

\begin{tabular}{l|c|c|c|c}
\hline \multicolumn{1}{c|}{ Airway type } & $\begin{array}{c}\text { Prosser and } \\
\text { Wallace (2002) }\end{array}$ & $\begin{array}{c}\text { McPherson } \\
\text { (1993) }\end{array}$ & $\begin{array}{c}\text { Hartman et al. } \\
(1997)\end{array}$ & Paper values \\
\hline $\begin{array}{l}\text { Rectangular Airway-Clean } \\
\text { Airway (Coal and soft } \\
\text { rocks) }\end{array}$ & 0.0075 & 0.0090 & 0.0080 & 0.0073 \\
$\begin{array}{l}\text { Rectangular Airway-Some } \\
\begin{array}{l}\text { Irregularities (Coal and soft } \\
\text { rocks) }\end{array}\end{array}$ & 0.0087 & 0.0090 & 0.0091 & 0.0084 \\
$\begin{array}{l}\text { Metal Mine Drift } \\
\text { Metal Mine Ramp }\end{array}$ & 0.0088 & 0.0120 & 0.0269 & 0.0115 \\
\end{tabular}

Table 4. Percentage difference between paper and bibliographic values

\begin{tabular}{l|c|c|c|c}
\hline \multirow{2}{*}{ Airway type } & \multirow{2}{*}{ Paper values } & \multicolumn{3}{|c}{ Difference, \% } \\
\cline { 3 - 5 } & $\begin{array}{c}\text { Prosser and } \\
\text { Wallace (2002) }\end{array}$ & $\begin{array}{c}\text { McPherson } \\
(1993)\end{array}$ & $\begin{array}{c}\text { Hartman et al. } \\
(1997)\end{array}$ \\
\hline $\begin{array}{l}\text { Rectangular Airway- } \\
\text { Clean Airway }\end{array}$ & 0.0073 & 2.32 & 22.78 & 9.14 \\
$\begin{array}{l}\text { Rectangular Airway- } \\
\text { Some Irregularities }\end{array}$ & 0.0084 & 3.20 & 6.76 & 7.95 \\
$\begin{array}{l}\text { Potash Mine Drift } \\
\text { Potash Mine Ramp }\end{array}$ & 0.0115 & 23.68 & 4.08 & 133.30 \\
\hline
\end{tabular}

\section{CONCLUSIONS}

The characteristic friction factors in a potash mine using a room and pillar method have been determined. Despite each mine has its own characteristics, it has been achieved a framework for future studies related to mine ventilation in this type of exploitations.

The Chezy-Darcy and Atkinson equations have been employed to calculate the friction factor $\mathrm{k}$, using the parameters measured in the control points. Roughness of the airways is due to, basically, the exploitation method and the nature of the de deposit, which has a certain deformable properties that define the shape of the tunnels.

\section{ACKNOWLEDGMENTS}

This work was supported by the Iberpotash Chair in mining sustainability from the Polytechnic University of Catalonia (UPC). The authors would like to thank the staff of Iberpotash S.A. for their willingness as well as postgraduate student Hernan Francisco Anticoi for important contributions.

\section{REFERENCES}

1. Shalimov, A.V., Numerical Modeling of Air Flows in Mines under Emergency State Ventilation, J. Min. Sci., 2011, vol. 47, no. 6, pp. 807-813.

2. Duckworth, I., and Prosser, B., Analysis of the Data Obtained from Ventilation Studies of Longwall Panels, Proc. 6th Int. Mine Ventilation Congress, 1997, pp. 223-229.

3. Alymenko, N.I., Aerodynamic Parameters of Ventilating Passages Joined-Up with the Main Mine Fan, $J$. Min. Sci., 2012, vol. 47, no. 6, pp. 814-823. 
4. McElroy, G., Engineering Factors in the Ventilation of Metal Mines, Bureau of Mines, U.S. Deparment of Interior, Washington, 1935.

5. Duckworth, I. J., Loomis, I., and Prosser, B., Fifteen Years of Resistance Data Collected at Freeport Indonesia, Proc. 14th U.S./North American Mine Ventilation Symposium, 2012, pp. 161-166.

6. Fytas, K., and Gagnon, C., A Database of Ventilation Friction Factors for Quebec Underground Mines, Proc. 14th U.S./North American Mine Ventilation Symposium, 2008, pp. 615-622.

7. Hall, C.J., Mine Ventilation Engineering, The Society for Mining, Metallurgy, and Exploration, Inc., 1981.

8. Hartman, H., Mutmansky, J., Ramani, R., and Wang, Y, Mine Ventilation and Air Conditioning, 3rd Edition, Vancouver: John Wiley and Sons, 1997.

9. Kharkar, R., Stefanko, R., and Ramani, R.V., Analysis of Leakage and Friction Factors in Coal Mine Ventilation Systems, Special Research Report No. SR-99, Pennsylvania Department of Commerce, 1974.

10. Prosser, B.S., and Wallace, K.G., Practical Values of Friction Factors, Proc. 8th US Mine Ventilation Symposium, 1999, pp 691-696.

11. Wala, A.M., Studies of Friction Factor for Kentucky’s Coal Mines, Proc. 5th U.S. Mine Ventilation Symposium, 1991, pp. 675- 684.

12. Prosser, B., and Wallace, K., Practical Values of Friction Factors, Mine Ventilation Service, Inc., California, USA 2002.

13. Diego, I., Torno, S., Toraño, J., Menéndez, M., and Gent, M., A Practical Use of CDF for Ventilation of Underground Works, Tunnelling and Underground Space Technology, 2011, pp. 189-200.

14. Montecinos, C., and Wallace, K., Equivalent Roughness for Pressure Drop Calculations in Mine Ventilation, Proc. 13th U.S./North American Mine Ventilation Symposium, 2010, pp. 225-230.

15. McPherson, M.J., Subsurface Ventilation and Environmental Engineering, Mine Ventilation Services, Inc., California, USA, 2009.

16. Hurtado, J.P., Díaz, N., Acuña, E.I., and Fernández, J., Shock Losses Characterization of Ventilation Circuits for Block Caving Production Levels, Tunnelling and Underground Space Technology, 2014, vol. 41, pp. 88-94.

17. Meyer, C., Determining the Friction Factors for Underground Colliery Board and Pillar Working, Safety in Mines Research Advisory Committee, 1998.

18. Carrasco Galan, J., Manual de ventilación de minas y obrassubterráneas (Please give English translation here), Aitemin Centro Tecnológico, Espanya, Madrid, 2011.

19. Box, G.E.P., Hunter J.S. and Hunter, W.G., Statistics for Experiments. Design, Innovation and Discovery, New Jersey: Wiley \& Sons, 2005. 